\title{
Association for Chemoreception Sciences (AChemS)
}

AChemS IV, the fourth annual meeting of the Association for Chemoreception Sciences, was held April 14-18, 1982, in Sarasota, Florida, with 204 in attendance. Forty-eight oral presentations and 65 posters covered anatomical, neurophysiological, biochemical, and behavioral research on the chemical senses across a great number of species.

The AChemS Executive Committee for 1982-1983 comprises: Past Chairperson-Gordon M. Shepherd (Yale University), Chairperson-Bruce P. Halpern (Cornell University), Chairperson-elect-William S. Cain (Pierce Foundation, Yale University), Secretary-Rose Marie Pangborn (University of California, Davis), Treasurer-John Caprio (Louisiana State University), Membership-Charlotte M. Mistretta (University of Michigan), CouncilorsRobert J. O'Connell (Worcester Foundation) and Michael Meredith (Florida State University). Marion E. Frank (University of Connecticut) will chair the program committee.

AChemS V is scheduled for April 27-May 1, 1983, at the Hyatt Hotel in Sarasota, Florida. Formal programs are scheduled for each evening, Wednesday through Saturday, with oral presentations in the mornings, Thursday through Sunday. Posters will be displayed all day Friday and Saturday, with authors in attendance during the corresponding evenings. Abstracts for both oral and poster presentations are due January 15, 1983. Standard forms may be obtained from M. E. Frank, Health Center, Department of Oral Biology, University of Connecticut, Farmington, Connecticut 06032 [(203) 674-3354].

An AChemS newsletter will be initiated in 1983. Contributions (announcements of past and future meetings, special publications or reviews, job openings, special services, etc.) should be sent to the Secretary by December 1, 1982.

Dues for calendar year 1983 are $\$ 20$ for professional members and $\$ 10$ for students. Checks should be made payable to AChemS and sent to C. M. Mistretta, Department of Oral Biology, School of Dentistry, University of Michigan, Ann Arbor, Michigan 48109.

Further information about AChemS is available from the Executive Chairperson, B. P. Halpern, Psychology and Neurobiology \& Behavior, Uris Hall, Cornell University, Ithaca, New York 14853 [(607) 256-6433/3834], or from the Secretary, R. M. Pangborn, Food Sciences \& Technology, University of California, Davis, California 95616 [(916) 752-2168]. 